\title{
8 The coming of the railways to Belgium, 8 Gioachino Rossini
}

Belgium was the first country in continental Europe to operate a steam railway, to create a national railway network and to possess a nationalised railway system. The first Belgian line connected its two main cities- Brussels and Antwerp. The line was completed in 1836 thus providing a route between the capital and the port without the need to use the inland waterways. The first lines and locomotives were imported from Britain and the first three locomotives to be used on the line were provided by George Stephenson's company. The completion of the first line was followed by a frenzy of railway building with lines extending to every main point of this small country creating the densest railway system in Europe. ${ }^{1}$

It may seem odd to feature the Italian composer Gioachino Rossini under the heading of the coming of the railways to Belgium. Furthermore, it is often stated that Rossini hated trains. However, many believe that his piano piece Un petit train de plaisir comico-imitatif (A little train of pleasure) which describes a catastrophic train journey was written at least partly in response to an unnerving experience he had when travelling from Antwerp to Brussels in 1836, its first year of operation. According to Macalpine and Hunter,

he actually fainted during the journey and was so shaken that he was ill for many days after. He found it indeed so terrifying an experience that he swore never to set foot on a train again. And he never did, although this often meant lengthier and more arduous journeys by coach. ${ }^{2}$

We will never know what Rossini found so frightening, but we do know that Rossini was affected by nervous diseases throughout his life and that the train journey in 1836 would, at best, certainly have been uncomfortable; even for 
first-class ticket holders, the compartments were cramped and there was no heating or lighting and no access to toilet facilities or refreshments. Matters were worse for second and third-class passengers who travelled in open wagons. As Simon Bradley puts it, 'Facilities for even the most expensive travel in the earliest railway years went little further than padded seats... Illumination was provided by God's own daylight and the internal climate was governed by the external one. ${ }^{3}$ The ride was bumpy in the early days, the springs (if there were any) were weak and the track was uneven.

Worse, the couplings between the coaches were not rigid....Every time the train set off or slowed down, passengers were thrown about. There was no brake mechanism to prevent the carriages bumping into each other and despite the padded seats in the superior carriages, complaints from the more well-todo travellers about their uncomfortable journey were frequent and sustained. ${ }^{4}$

Nevertheless, although Rossini may have abhorred the idea of train journeys, he built his villa in Passy on a site close to the railway line and invested part of his fortune in railway shares. ${ }^{5}$

\section{Gioachino Rossini}

The career of the Italian composer Gioachino Rossini (1792-1868) falls into two halves. In the first part of his life he was hugely prolific, he composed rapidly and fluently, and by the age of 38 he had written nearly 40 operas, many of these highly successful. Often nicknamed 'Signor Crescendo' to reflect his talent for whipping up musical excitement, he had achieved international fame and recognition. Several of his operas - notably The Italian Girl in Algiers, The Barber of Seville and Cinderella - still form a significant part of today's standard repertoire. But Rossini's career as a stage composer spanned only nineteen years. In 1829 he composed William Tell, and this was to be his final opera, his career came to an abrupt end and he withdrew from society.

In 1855, 25 years later, he settled in Paris with his second wife, Olympe Pélissier. He bought a piece of land in the suburb of Passy where he built a villa as well as renting a place in the city quarters. He eventually re-emerged into society: his health improved; his joie de vivre returned; and remarkably he began to compose again. There were no more operas but there was a surge 
of composition, one large scale religious work the Petite Messe solennelle along with over 150 piano pieces, songs, and small ensembles that he referred to with the self-deprecating title Péchés de vieillesse (Sins of old age) (1857-68). Many of the smaller works were written to be performed at the Rossinis' 'Samedi soirs' a series of elegant salons held at their two Parisian homes between 1858 and 1868, the year of the composer's death. The 'Samedi soirs' soon became established as the most sought after artistic and intellectual gatherings and along with important public figures, the Rossinis were host to eminent composers, singers and instrumentalists including Wagner, Verdi, Liszt, Joachim and Rubinstein.

\section{Un petit train de plaisir comico-imitatif (A little train of pleasure) - Gioachino Rossini ${ }^{6}$}

The Péchés de vieillesse were written for Rossini's own amusement, to be performed in the privacy of his drawing room. He refused to allow them to be published and kept the manuscripts under lock and key in a mahogany chest in his bedroom.? They remained barely known until the Fondazione Rossini began editing them in the 1950s. Each of the piano pieces has a witty, often nonsensical title, such as Prélude prétentieux and Valse torturée. They are often humorous and sometimes mocking. Many of them are parodies of other composers or styles as revealed in their titles. In Petit caprice (style Offenbach) the tempo indication is 'Allegretto grotesco' and the music is reminiscent of a rather inebriated Offenbach cancan. Some of the pieces, including 'Un petit train de plaisir' include an often satirical running commentary written on the score. The composer who is most well-known for peppering his scores with such whimsical instructions and witty remarks is Erik Satie $(1866$ - 1925) so there has been some speculation as to whether Satie was influenced in any way by Péchés de vieillesse. This seems unlikely given that Satie had probably not seen or heard any of this music when he was composing his own since the Péchés de vieillesse had not been published at this time.

What follows is a potted version of 'Un petit train de plaisir comico-imitatif', a disastrous train journey translated into sound, what Richard Osborne describes as a not altogether amusing piano piece... in which genial mimicry of the train's progress is overtaken by a fatal derailment, the contemplation of the flight of the victims' souls and a sardonic coda in which the heirs of the more well-to-do victims cut a few celebratory capers.' 
The signal bell sounds and the passengers climb into the carriages:

(Cloche d'Appel)

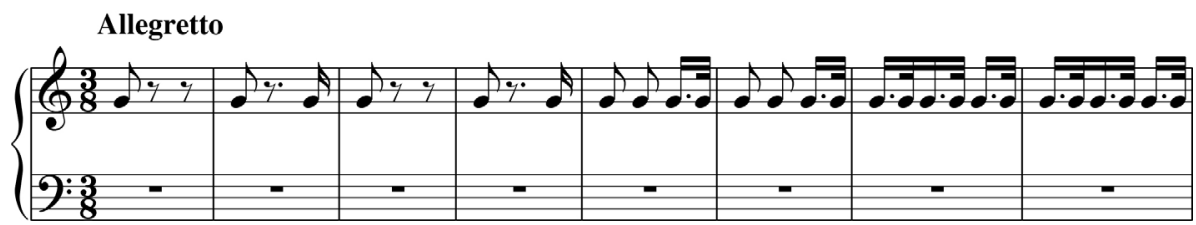

Off goes the train, slowly gathering momentum:

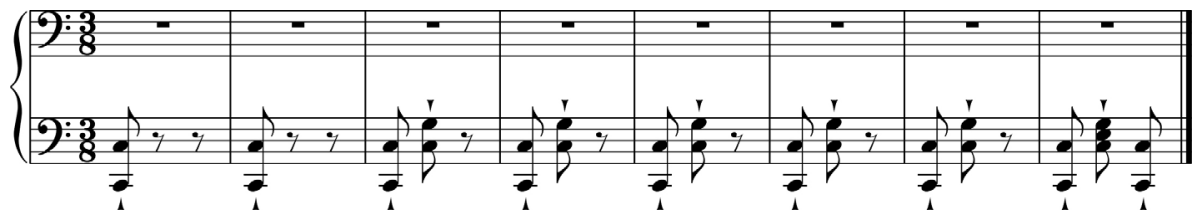

A satanic whistle sounds:

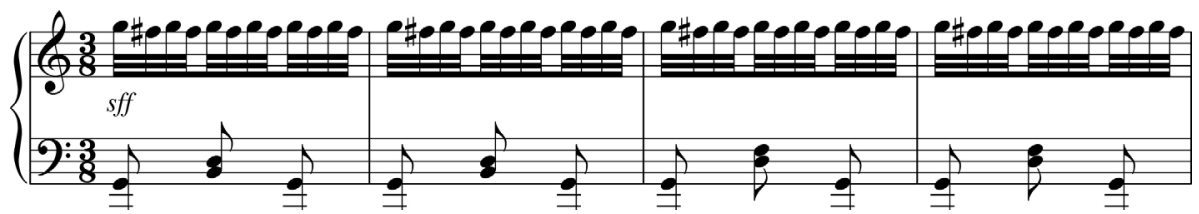

Next we hear what Rossini describes (with a hint of sarcasm) as the 'Douce mélodie du Frein' (Sweet melody of the brakes). The music quietly runs down a chromatic scale, which could hardly be described as a melody, getting louder as it descends into the lower octaves then dying away and coming to a full stop and a pause as it arrives at the station. A slower more romantic passage follows with the comment: 'Les Lions Parisiens offrant la main aux Biches pour descendre du Wagon' (The Parisian Lions offering a hand to the Does to disembark from the carriage). This rather more obscure observation may have been a private joke for the salon gathering with the 'lions' referring to 'men' and the 'does' referring to 'women'. Just as in the wild lions prey upon does, perhaps the men are helping the women down from the carriages, but with wicked intent.

The journey continues but a terrible disaster is ahead. The convoy comes off the rails depicted by a chain of very loud and discordant diminished sevenths: 
(Terrible deraillment du convoi)

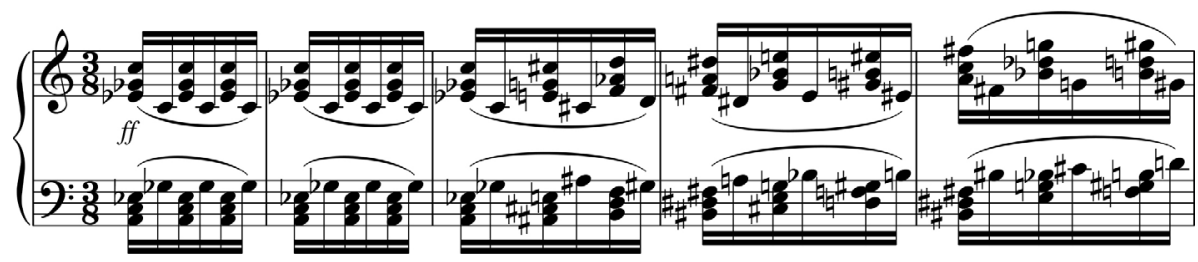

A first person is hurt and then a second. With a touch of irony, the first fatality rises up into Heaven with an ascending minor arpeggio whilst the second casualty goes down to Hell with a descending major arpeggio. Rossini has turned the standard major (happy)/minor (sad) convention on its head:
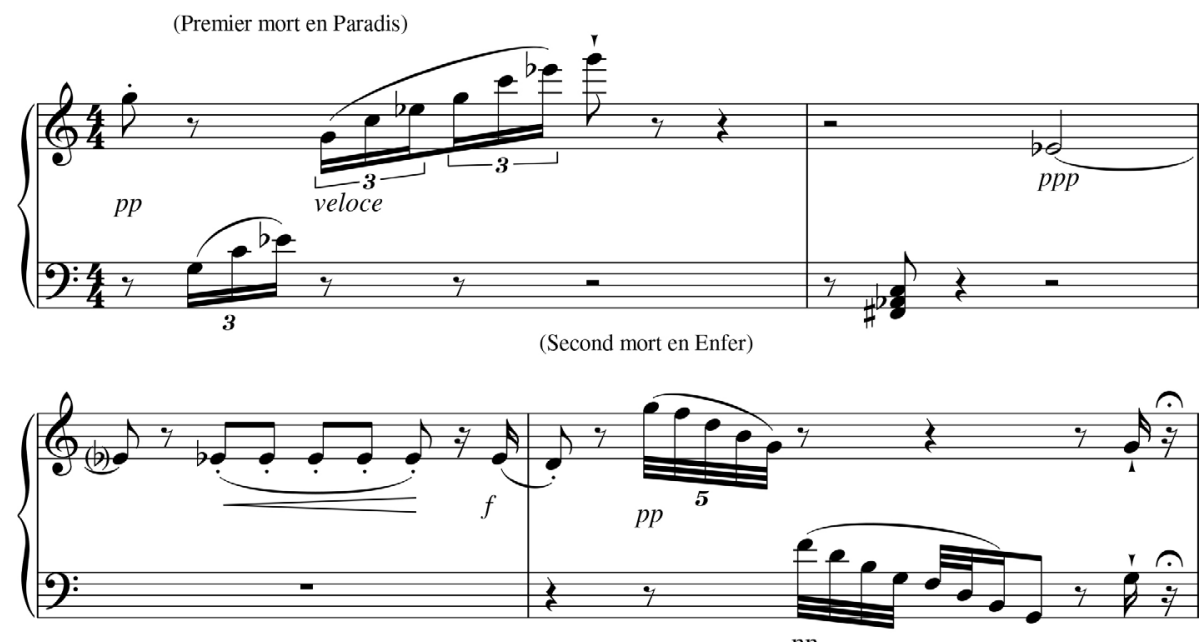

$p p$

This passage leads into a more conventional funeral song with quiet slowmoving chords, many of them minor, bearing a noticeable similarity to both Chopin's funeral march and the slow movement of Beethoven's Symphony No. 7.9 Perhaps this pastiche was another in-joke for the salon gathering that would no doubt have been familiar with both pieces. 


\section{Ex 24 Rossini (f)}

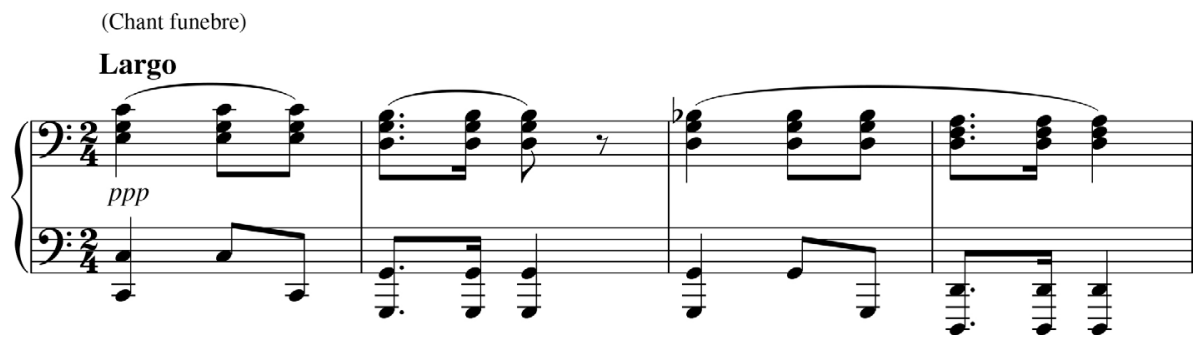

The acute sorrow of the heirs, who will of course inherit the fortunes of those killed in the accident, is depicted with a note of cynicism by a carefree melody which is far from sorrowful. The piece continues in an exuberant vein, ending with exultant flourishes and loud $\mathrm{C}$ major chords. The irony is reinforced by the final observation 'Tout ceçi est plus que naîf: c'est vrai!' (All of this is more than naïve: it is true).

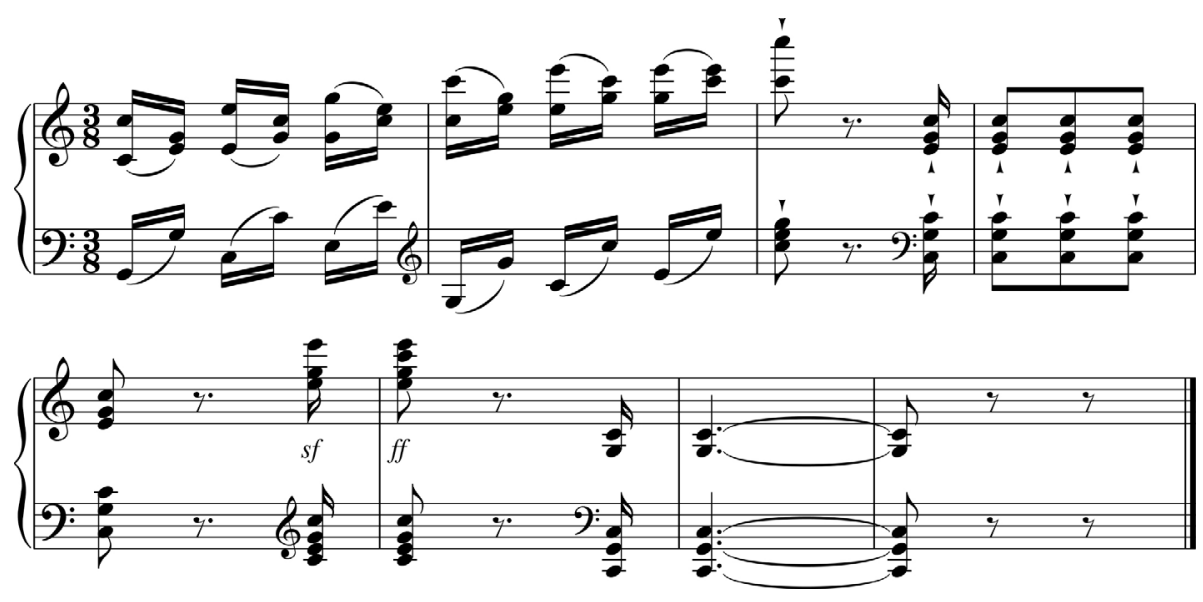




\section{Endnotes}

1 Christian Wolmar. Blood, Iron and Gold: How the Railways Transformed the World (Great Britain: Atlantic Books, 2010): 21.

2 Ida Macalpine and Richard A Hunter. "Rossini: Piano Pieces for the Primal Scene" American Imago, 9, No. $3 / 4$ (1952): 217.

3 Simon Bradley. The Railways: Nation, Network and People (London: Profile Books, 2015): 133.

4 Christian Wolmar. A Short History of Trains. (London: Dorling Kindersley Ltd., 2019): 147.

5 Macalpine and Hunter, "Rossini: Piano Pieces for the Primal Scene", 217.

6 Different versions of the title can be found for this piece. A comma is commonly used after the word 'plaisir', for example and sometimes the French 'comique' is used rather than the Italian 'comico'. It is not clear what is meant by 'comico-imitatif'. It does not appear to be a genre as further examples of such a genre cannot be found. Sometimes it is translated as 'comic and imitative' no doubt referring to both the tongue-in-cheek comments and the music which, at points, imitates a train.

7 The Times, 27 December, 1968.

8 Richard Osborne. "Off the stage". In The Cambridge Companion to Rossini, edited by Emanuele Senici. (Cambridge: Cambridge University Press, 2007): 134.

9 The Marche Funèbre of Chopin's Piano Sonata No. 2 (1839) and the Allegretto movement of Beethoven's Symphony No. 7 in A (1812). 
10.5920/railways. 8 